\title{
Implementasi Konseling Islami: Negoisasi Identitas Spiritual Dalam Tradisi Tarekat Naqsabandiyah di Sumatera Utara
}

\author{
Syawaluddin Nasution, Miswar, Pangulu Abdul Karim \\ Universitas Islam Negeri Sumatera Utara, Medan \\ syawaluddin69@gmail.com \\ miswarrasyidr@gmail.com \\ panguluabdulkarim123@gmail.com
}

\begin{abstract}
ABSTRAK
Praktik konseling islami dalam tradisi tarekat terkait dengan proses bagaimana seorang tuan guru memberikan pengenalan, pemahaman dan kemampuan dalam mengambil keputusan yang didasarkan pada ajaran Islam. Untuk itu tulisan ini bertujuan untuk menelusuri praktik konseling islami yang dilakukan tuan guru di persulukan Naqsabandiyah, meliputi (1) pendekatan yang digunakan tuan guru dalam mengenal dan memahami diri Iself), (2) penerapan teknik attending dalam melayani para salik serta (3) dimensi konseling islami dalam proses pengambilan keputusan yang dilakukan para salik. Tulisan ini disusun melalui kajian literature terkait tema tersebut. Hasilnya membuktikan bahwa praktik konseling tuan guru dalam membimbing para salik dimulai dari kajian untuk mengenal diri, fokus dan konsisten terhadap pemahaman salik dalam mengambil keputusan. Melalui aktivitas ini tuan guru sebagai pemimpin tarekat mempraktikkan proses konseling. Dengan demikian, tradisi dalam tarekat yang dilaksankan tuan guru sejalan dengan tujuan, prinsip, dan azas konseling islami (konseling konvensional yang diberi karakter Islam).

Kata Kunci: konseling islami, tarekat Naqsabandiyah dan tuan guru
\end{abstract}

\section{PENDAHULUAN}

Manusia dilahirkan didunia dengan dibekali akal, pikiran, dan perasaan. Dengan bekal itulah manusia disebut sebagai makluk yang paling sempurna dan diamanati oleh sang pencipta sebagai pemimpin di bumi ini. Akan tetapi seiring dengan bekal akal, pikiran dan perasaan itu pula manusia diselimuti oleh berbagai macam masalah, bahkan ada yang mengatakan bahwa manusia merupakan makhluk dengan segudang masalah (human with multiproblem). Dengan berbagai masalah itu ada yang bisa mereka atasi dengan sendirinya atau mereka memerlukan bantuan orang lain (konselor) untuk mengatasi masalah yang dihadapinya. Dan pemberian bantuan dari orang yang ahli (konselor) kepada individu yang membutuhkan (klien) itulah yang dinamakan "konseling".

Dalam memecahkan masalahnya, manusia memiliki banyak pilihan cara, salah satunya adalah dengan cara islam. Mengapa islam? Karena islam mengatur seluruh aspek kehidupan manusia tak terkecuali berkenaan dengan bimbingan dan konseling. Dalam paper ini kami akan memaparkan berbagai hal terkait dengan bimbingan konseling islam, termasuk tujuan-tujuan dari bimbingan konseling islam dan bagaimana ketika bimbingan dan konseling di implementasikan tuan guru dalam kajian Tarekat Naqsabandiyah 


\section{KONSELING ISLAM: SEBUAH PENGANTAR}

Berdasarkan literature bahasa Arab kata konseling disebut $\mathrm{Al}$ Irsyad atau Al-Istisyarah, dan kata bimbingan disebut Attaujih. Dengan demikian, Guidance and Counselling dialih bahasakan menjadi At-taujih wa alirsyad atau at-taujih wa al-istisyarah.

Secara etimologi kata Irsyad berarti alhuda, ad-dalah yang dalam bahasa Indonesia berarti petunjuk, sedangkan kata Al istisyarah berarti; talaba min almansyurah/an-nasihah, dalam bahasa Indonesia berarti; meminta nasehat/konsultasi. Sementara Bimbingan Islami adalah proses pemberian bantuan terhadap individu agar mampu hidup selaras dengan ketentuan dan petunjuk Allah, sehingga dapat mencapai kebahagiaan hidup di dunia dan di akhirat. Kesempurnaan ajaran Islam menyimpan khazanah-khazanah berharga yang dapat digunakan untuk membantu menyelesaikan problem kehidupan manusia. Secara operasional khazanah-khazanah tersebut tertuang dalam konsep konseling Islami dan secara praktis tercermin dalam proses face to face relationship (pertemuan tatap muka) atau personal contact (kontak pribadi) antara seorang konselor professional dan berkompeten dalam bidangnya dengan seorang klien/konseli yang sedang menghadapi atau berjuang menyelesaikan kehidupannya untuk mewujudkan amanah ajaran Islam.

Konseling Islam akan menjalin hubungan personal antara dua pihak manusia, satu pihak ingin memecahkan / menyelesaikan problem kehidupannya untuk mewujudkan amanah ajaran Islam. Konseling Islam akan menjalin hubungan personal antara dua pihak manusia, satu pihak ingin memecahkan/menyelesaikan masalah dan satu pihak lagi membantu memecahkan atau menyelesaikan masalah. Hasil seminar bimbingan dan konseling Islami yang diselenggarakan oleh UII di Yogyakarta pada tahun 1985 didapat sebuah rumusan bahwa "Konseling Islami adalah proses pemberian bantuan terhadap individu agar menyadari kembali eksistensinya sebagai makhluk Allah yang seharusnya hidup selaras dengan ketentuan dan petunjuk Allah, sehingga dapat mencapai kebahagiaan di dunia dan diakhirat".

Sejalan dengan hal itu, Hellen mengungkapkan bahwa Konseling Islam adalah suatu usaha membantu individu dalam menanggulang penyimpangan perkembangan fitrah beragama yang dimilikinya, sehingga ia kembali menyadari perannya sebagai khalifah Allah di muka bumi dan berfungsi untuk mengabdi kepada Allah SWT sehingga akhirnya tercipta kembali hubungan yang baik dengan Allah, dengan manusia dan alam semesta.Berpijak pada beberapa pendapat di atas dapat kita pahami bahwa konseling Islam adalah upaya bantuan yang diberikan oleh seorang konselor kepada klien agar klien dapat menyelesaikan masalahnya dengan menggunakan Al-Qur'an dan hadist sebagai pedoman untuk bertindak. Senada dengan hal tersebut, Tohari Musnamar mengemukakan bahwa Bimbingan dan Konseling Islam adalah proses pemberian bantuan terhadap individu agar menyadari kembali akan eksistensinya sebagai makhluk Allah yang seharusnya hidup selaras dengan ketentuan dan petunjuk Allah, sehingga dapat mencapai kebahagiaan di dunia dan di akhirat. Berdasarkan pendapat di atas dapat kita pahami bahwa konseling Islam merupakan sebuah proses konseling yang menjadikan Alquran dan Sunnah sebagai pedoman agar 
individu tersebut dapat menyelesaikan masalahnya dan menyadari keberadaannya sebagai makhluk Allah SWT. ${ }^{1}$

Thohari Musnamar membagi tujuan bimbingan dan konseling Islami menjadi tujuan umum dan tujuan khusus. Adapun tujuan umum dari bimbingan dan konseling Islam adalah membantu individu mewujudkan dirinya menjadi manusia seutuhnya agar mencapai kebahagiaan hidup di dunia dan di akhirat. Tujuan khusus bimbingan dan konseling Islami adalah;pertama, Membantu individu agar tidak menghadapi masalah. Kedua, Membantu individu mengatasi masalah yang dihadapi.Ketiga, Membantu individu memelihara dan mengembangkan situasi dan kondisi yang baik atau yang telah baik agar tetap baik atau menjadi lebih baik, sehingga tidak akan menjadi sumber masalah bagi dirinya dan orang lain.

Tujuan konseling Islami menurut Hamdani Bakran Adz-Dzuki, adalah :pertama, Untuk menghasilkan suatu perubahan, perbaikan, kesehatan, dan kebersihan jiwa dan mental. Jiwa menjadi tenang, jinak dan damai (muthmainah), bersikap lapang dada (radhiyah) dan mendapatkan pencerahan taufik dan hidayah Tuhannya (mardhiyah).Kedua, Untuk menghasilkan suatu perubahan, perbaikan dan kesopanan, tingkah laku yang dapat memberikan manfaat baik pada diri sendiri, lingkungan keluarga, lingkungan kerja, maupun lingkungan social dan alam sekitarnya.Ketiga, Untuk menghasilkan kecerdasan rasa (emosi) pada individu sehingga muncul dan berkembang rasa toleransi, kesetiakawanan, tolongmenolong dan rasa kasih sayang.Keempat, Untuk menghasilkan kecerdasan spiritual pada diri individu sehingga muncul dan berkembang rasa keinginan untuk berbuat taat kepada Tuhannya, ketulusan mematuhi segala perintah-Nya, serta ketabahan untuk menerima ujian-Nya.Kelima, Untuk menghasilkan potensi ilahiyyah, sehingga dengan potensi itu individu dapat melakukan tugasnya sebagai khalifah dengan baik, menanggulangi berbagai persoalan hidup dan dapat memberikan kemanfaatan dan keselamatan bagi lingkungan pada berbagai aspek kehidupan. ${ }^{2}$ Asas bimbingan dan konseling Islam berdasarkan al-Qur'an dan Sunnah Nabi di tambah berbagai landasan filosofis dan landasan keimanan, yaitu :prtama, Tujuan bimbingan dan konseling Islam adalah membantu klien mencapai kebahagiaan hidup yang senantiasa didambakan setiap manusia.Kedua, Bimbingan dan konseling Islam merupakan bantuan kepada klien yang mengenal, memahami, dan menghayati fitrahnya, sehingga segala gerak dan tingkah laku serta tindakkannya berjalan dengan fitrah. Fitrah tersebut. Manusia menurut Islam dilahirkan dalam keadaan fitrah, yaitu berbagai kemampuan potensi bawaan dan kecenderungan sebagai muslim atau beragama Islam.Ketiga, Bimbingan dan konseling Islam ini dilaksanakan semata-mata karena Allah SWT. Konsekuensi dari asas ini berarti pembimbing melakukan tugas dengan penuh keikhlasan. Klien pun menerima, meminta bimbingan dan konseling dengan ikhlas dan rela pula karena semua pihak merasa bahwa semua yang dilakukan karena untuk pengabdian kepada Allah SWT semata, sesuai dengan fungsi dan tugasnya sebagai makhluk Allah yang harus senantiasa mengabdi kepada-Nya. Firman Allah surat al-Bayinah ayat 5 Artinya : "Padahal mereka tidak disuruh kecuali supaya menyembah Allah dengan memurnikan ketaatan kepada-Nya dalam (menjalankan) agama yang lurus, dan supaya mereka mendirikan shalat dan 
menunaikan zakat; dan yang demikian Itulah agama yang lurus"keempat, Bimbingan dan konseling merupakan bagian dari komponen pendidikan. Oleh karena itu, pemberian layanan bimbingan dan konseling dilakukan sepanjang hidup manusia. Manusia yang hidup di dunia tidak ada yang selalu bahagia kadang kala dalam kehidupan ini akan menjumpai berbagai kesulitan dan kesusahan. Untuk itu di perlukan bimbingan dan konseling Islami yang diharapkan bisa mengatasi semua permasalahan hidup sepanjang hayat.Kelima, Bimbingan dan konseling Islami memandang manusia sebagai makhluk jasmaniah-rohaniah tidak memandang sebagai makhuk jasmaniah semata. Untuk itu bimbingan dan konseling Islami membantu individu untuk hidup seimbang jasmaniah dan rohaniah. Keenam, Allah telah memuliakan manusia dengan kelebihan-kelebihan atau keutamaan-keutamaan yang tidak diberikan kepada makhuk lain selain manusia. Ketujuh, Bimbingan dan konseling Islam melihat kepada citra manusia menurut Islam. Seseorang melihat eksistensi tersendiri. Individu mempunyai hak, mempunyai perbedaan kemerdekaan pribadi. Kedelapan, Manusia merupakan makhluk social. Hal ini di akui dan diperhatikan dalam Bimbingan dan konseling Islam. Pergaulan, cinta kasih, rasa aman, penghargaan terhadap diri sendiri dan orang lain, rasa memiliki dan dimiliki, merupakan aspek-aspek yang diperhatikan dalam Bimbingan dan konseling Islami. Dalam bimbingan dan konseling Islami, sosialitas manusia diakui dengan memperhatikan hak individu dalam batas tanggung jawab sosial.

Kesembilan, Manusia menurut pandangan Islam diberikan kedudukan yang tinggi sekaligus tanggung jawab yang besar, yakni mengelola alam, semesta dengan kata lain, manusia di pandang makhluk yang berbudaya yang mengelola alam sekitar sebaik-baiknya. Firman Allah surat Fathir ayat 39 Artinya : "Dia-lah yang menjadikan kamu khalifah-khalifah di muka bumi. barangsiapa yang kafir, Maka (akibat) kekafirannya menimpa dirinya sendiri. dan kekafiran orang-orang yang kafir itu tidak lain hanyalah akan menambah kemurkaan pada sisi Tuhannya dan kekafiran orang-orang yang kafir itu tidak lain hanyalah akan menambah kerugian mereka belaka". Kesepuluh, Islam menghendaki keharmonisan, keselarasan, keseimbangan, keserasian, dalam segala segi. Dengan kata lain, Allah menginginkan manusia berlaku adil terhadap diri sendiri, alam semesta, dan juga kepada Allah SWT. Kesebelas, Bimbingan dan konseling Islam membantu klien atau yang dibimbing memelihara, mengembangkan sifat-sifat yang baik sejalan dengan tugas dan fungsi Rasulullah di utus oleh Allah SWT.

Keduabelas, Setiap manusia memerlukan cinta, kasih sayang dan rasa sayang dari orang lain. Rasa kasih sayang ini dapat mengalahkan dan menundukkan banyak hal. Bimbingan dan konseling Islam dilakukan dengan berlandasan kasih sayang, sebab dengan kasih sayang pemberian bimbingan dan konseling akan menyentuh hati dan tujuan akan cepat tercapai.Ketiga belas, Bimbingan dan konseling Islam dilakukan dengan asas musyawarah artinya antara pembimbing dengan yang di bimbing terjadi dialog yang baik, satu sama lain tidak mendiktekan, tidak ada rasa tertekan dan terbuka dalam berpendapat.

Ketiga belas, Bimbingan dan konseling Islam dilakukan oleh orang-orang yang memang memiliki kemampuan dan keahlian di bidang tersebut, baik keahlian dalam metodologi maupun keahlian dalam teknik-teknik bimbingan dan 
konseling. ${ }^{3}$ Fungsi bimbingan dan konseling Islami dapat dirumuskan sebagai berikut : Pertama, Fungsi preventif, yakni membantu individu menjaga atau mencegah timbulnya masalah bagi dirinya. Kedua, Fungsi kuratif atau korektif, membantu individu memecahkan masalah yang sedang di hadapi atau di alamiketiga, Fungsi preservatif, yakni membantu individu menjaga agar situasi atau kondisi yang semula tidak baik telah menjadi baik (terpecahkan ) itu kembali menjadi tidak baik (menimbulkan masalah kembali).Keempat, Fungsi developmental atau pengembangan, yakni membantu individu memelihara dan mengembangkan situasi dan kondisi yang telah baik agar tetap baik dan menjadi lebih baik, sehingga tidak memungkinkan menjadi sebab munculnya masalah baginya.

Berdasarkan fungsi bimbingan dan konseling Islami di atas, terlihat bahwa substansi layanan tersebut adalah untuk memecahkan setiap persoalan yang di hadapi oleh peserta didik terutama pada masa remaja dalam kehidupan sehari-hari serta mengusahakan sedapat mungkin agar masalah yang sama tidak terulang lagi. Fungsi konseling secara implementasinya, maka bimbingan konseling dan islam sebagai berikut : Pertama, mengetahui, mengenal dan memahami akan eksistensi dan fitrahnya kedua, membantu individu menerima keadaan dirinya sebagaimana adanya, atau membantu individu tawakal atau berserah diri kepada allah. Ketiga, membantu individu merumuskan masalah yang dihadapinya dan membantunya menyelesaikan masalah yang ssedang dihadapinya. Keempat, Membantu individu menemukan alternatif pemecahan masalah sesuai dengan kadar intelektual masing - masing individu, sperti yang di anjurkan al - qur'an yaitu, berlaku sabar, membaca dan memaahami al - qur'an, dan berdzikir. Kelima, membantu individu dalam mengembangkan kemampuan pengantisipasi masa depan, sehingga akan bertindak secara hati - hati dan penuh pertimbangan di dalam memilih alternatif tindakan.Islam, dalam aplikasi penyebaran ajarannya banyak menggunakan metode bimbingan dan konseling, sebagaimana di jelaskan Musfir bin Said Az Zahrani, diantaranya sebagai berikut :pertama, Metode keteladanan, yang di gambarkan dengan suri tauladan yang baik, sebagai firman allah: (Al-Ahzab:21):

Artinya: Sesungguhnya telah ada pada (diri) Rasulullah itu suri teladan yang baik bagimu (yaitu) bagi orang yang mengharap (rahmat) Allah dan (kedatangan) hari kiamat dan Dia banyak menyebut Allah.

Kedua, Metode penyadaran, metode ini banyak menggunakaan ungkapan - ungkapan nasehat dan juga at-targhib wa-tarhib (janji dan ancaman. Sebagaimana dijelaskan dalam firman allah dalam surat Al-Hajj ayat 1-2:

Artinya: Hai manusia, bertakwalah kepada Tuhanmu; Sesungguhnya kegoncangan hari kiamat itu adalah suatu kejadian yang sangat besar (dahsyat). (ingatlah) pada hari (ketika) kamu melihat kegoncangan itu, lalailah semua wanita yang menyusui anaknya dari anak yang disusuinya dan gugurlah kandungan segala wanita yang hamil, dan kamu Lihat manusia dalam Keadaan mabuk, Padahal sebenarnya mereka tidak mabuk, akan tetapi azab Allah itu sangat kerasnya. Ketiga, Metode penalaran logis, metode ini berkisaran tentang dialog dengan alasan akal atau

3 http://kandidatkonselor.blogspot.com/2013/02/bimbingan-dan-konseling-islam-ii.html 
logika dan perasaan individu, sebagaimana firman allah SWT. yang di jelaskan dalam surat Al-Hujuraat : 12 :

Artinya :Hai orang-orang yang beriman, jauhilah kebanyakan purba-sangka (kecurigaan), karena sebagian dari purba-sangka itu dosa. dan janganlah mencaricari keburukan orang dan janganlah menggunjingkan satu sama lain. Adakah seorang diantara kamu yang suka memakan daging saudaranya yang sudah mati? Maka tentulah kamu merasa jijik kepadanya. dan bertakwalah kepada Allah. Sesungguhnya Allah Maha Penerima taubat lagi Maha Penyayang.

Keempat, Metode kisah (cerita). Al-Qur'an banyak merangkum kisah kisah para nabi serta dialog yang terjadi diantara mereka dengan kaumnya. Kisah ini bisa dijadikan sebagai contoh dan teladan serta model yang mampu menjadi penjelas akan perilaku - perilaku yang diharapkan, sehingga bisa dibiaskan, dan juga perilaku - perilaku yang tercela sehingga bisa dihindari. ${ }^{4}$ Pembimbing atau konselor adalah seseorang yang karena keahlian memberikan bantuan kepada orang lain yang mengalami kesulitan-kesulitan atau masalah-masalah yang mana orang tersebut tidak bisa mengatasinya sendiri tanpa bantuan orang lain. MenurutSayuti, Pembimbing adalah orang yang mempunyai kompetensi (kewenangan) untuk melakukan bimbingan dan konseling Islami. Sedangkan dalam buku "Bimbingan dan Konseling Islami" pembimbing adalah orang yang menguasai bimbingan dan konseling sosial Islami.Adapun syarat-syarat untuk menjadi pembimbing atau konselor yaitu:pertama, Memiliki tiga sikap pokok antara lain:pertama, Sikap menerima berarti bahwa konselor menerima siswa sebagai adanya dan tidak segera "mengadili" siswa tentang kebenaran dari pendapat,perasaan ataupun perbuatannya.Kedua, Sikap ingin memahami menuntut dari pembimbing agar dia berusaha sekuat tenaga untuk menangkap dengan jelas dan lengkap hal-hal yang sedang dikemukakan oleh siswa, baik dengan kata-kata maupun dengan isyarat yang lain. Maka pembimbing atau konselor harus berusaha ikut merasakan(empaty) apa yang diungkapkan dan apa yang dialami oleh siswa.Ketiga, Sikap bertindak dan berbicara secara jujur berarti bahwa konselor tidak boleh berpura-pura, sehingga dalam pandangan siswa pembimbing atau konselor kelihatan "spontan".Keempat, Kepekaan terhadap apa yang terdapat "dibelakang" kata-kata kelayan.Kelima, Kemampuan dalam cara berkomunikasi yang tepat (rapport).Keenam, Meskipun seorang pembimbing atau konselor di panti juga berfungsi sebagai pendidik, tetapi janganlah pembimbing itu bertindak/berlagak "dominan”.Ketujuh, Memiliki kesehatan jasmani dan mental yang layak.

Menaati kode etika jabatan, yang meliputi seperti sikap, ketrampilan, syarat pendidikan, penggunaan informasi yang diperoleh dari konseli, penggunaan testing, hak dan kewajiban anggota profesi konselor. ${ }^{5}$ Sedangkan syarat-syarat menjadi pembimbing atau konselorIslami sebagai berikut:pertama, Memiliki pribadi yang menarik, serta rasa berdedikasi yang tinggi dalam tugasnya.Kedua, Menyakini tentang mungkinnya anak bimbing mempunyai kemampuan untuk

4 Drs.Masdudi,M.Pd. 2012. Bimbingan Konseling Perspektif Sekolah. Cirebon : Al-Tarbiyah Press

5 Prof. DR.H.Mohamad Surya .2003.58-67 
berkembang sebaik-baiknya bila disediakan kondisi dan kesempatan yang fovurable untuk itu.Ketiga, Memiliki rasa commited dengan nilai-nilai kemanusiaan.Keempat, Memiliki kemampuan untuk mengadakan komunikasi baik dengan anak bimbing maupun lainnya.Kelima, Bersikap terbuka artinya tidak memiliki watak yang suka menyembunyikan sesuatu maksud yang tidak baik.Keenam, Memiliki keuletan dalam lingkungan tugasnya termasuk pula lingkungan sekitarnya.Ketujuh, Memiliki rasa cinta terhadap orang lain.Kedelapan, Memiliki perasaan sensitif terhadap kepentingan anak bombing kesembilan, Memiliki kecekatan berfikir, cerdas sehingga mampu memahami yang dikehendaki kelayan.Kesepuluh, Memiliki personality yang sehat dan bulat, tidak terpecah-pecah jiwa (frustasi). Kesebalas, Memiliki ketenangan jiwa (kedewasaan) dalam segala perbuatan lahiriyah dan batiniyahkeduabelas, Memiliki sikap mental suka belajar dalam ilmu pengetahuan yang berhubungan dengan tugasnyaketiga, belas, Bilamana pembimbinng tersebut bertugas di bidang agama, berakhlak mulia, serta aktif menjalankan ajaran agamanya dan sebagainya.

Syarat lain pembimbing atau konselor Islami dikelompokkan sebagai berikut:pertama, Kemampuan keahlian (professional)Pembimbing dam bimbingan konseling Islami tentu haruslah merupakan orang yang memiliki kemampuan keahlian atau professional di bidang tersebut. Dengan istilah lain dikatakan yang bersangkutan merupakan seorang "alim" di bidangnya. Keahlian (kealiman) dalam hal ini merupakan syarat mutlak, sebab apabila yang bersangkutan tidak menguasai bidangnya, maka bimbingan konseling tidak akan mencapai sasarannya, tidak akan berhasil. Hadits Nabi sebagai berikut: "Apabila sesuatu perkara diserahkan (penanganannya) kepada orang yang bukan ahlinya, tunggu sajalah saat (ketidak berhasilan atau kehancurannya)" (H.R.Bukhari).

Kedua, Sifat kepribadian yang baik (akhlakul-karimah)Siddiq (mencintai dan membenarkan kebenaran)Pembimbing harus memiliki sifat siddiq, yakni cinta pada kebenaran dan mengatakan sesuatu yang memang benar.Amanah (bisa dipercaya)Pembimbing harus dapat dipercaya, dalam arti yang bersangkutan mau dan mampu menjaga rahasia orang yang menjadi yang dibimbing.Tabliqh (mau menyampaikan apa yang layak disampaikan).Pembimbing harus bersedia menyampaikan apa yang layak disampaikan.Fatonah (intelejen, cerdas, berpengetahuan).Pembimbing harus memiliki kemampuan dan kecerdasan yang memadai, termasuk sifat inovatif, kreatif, cepat tanggap, cepat mengambil keputusan dan sebagainya. Pengetahuan dan ketrampilan yang luas diperlukan untuk bisa membimbing dengan efektif.Mukhlis (ikhlas dalam menjalankan tugas).Pembimbing harus ikhlas dalam menjalankan tugasnya karena mengharapkan ridha Allah (lillahi ta'ala). SabarPembimbing harus memiliki sifat sabar, dalam arti ulet, tabah, ramah, tidak mudah putus asa, tidak pernah marah, mau mendengarkan keluh kesah yang dibimbing dengan penuh perhatian dan sebagainya.Tawaduk (rendah hati)Pembimbing harus memiliki sifat rendah hati, tidak sombong, tidak merasa paling tinggi kedudukan maupun ilmunya dan sebagainya. Sebagaimana disebutkan dalam al-Quran;Saleh (mencintai, melakukan, membina, menyokong kebaikan).Pembimbing harus bersifat saleh, karena kesalehnnya itu akanmemudahkannya melakukan tugasnya dengan baik.AdilPembimbing dalam berlaku harus adil, dalam arti mampu mendudukkan permasalahan dan klien sesuai dengan situasi dan kondisinya secara porposional. 
Mampu mengendalikan diri.Pembimbing harus memiliki kemampuan kuat untuk mengendalikan diri, menjaga kehormatan diri dan kehormatan yang dibimbing.

Ketiga, Kemampuan kemasyarakatan (Hubungan sosial) Pembimbing harus memiliki kemampuan melakukan hubungan kemanusiaan atau hubungan sosial, ukhuwah Islamiyah yang tinggi. Keempat, Ketakwaan kepada Allah Ketakwaan mereka syarat dari segala syarat yang harus dimiliki seorang pembimbing, sebab ketakwaan merupakan sifat paling baik. ${ }^{6}$

Ilmu Thoroqoh Naqsyabandiyah bukan hanya ilmu yang mengutamakan akhirat semata, tapi juga ilmu yang efektif dan strategis untuk membina akhlak dan moral bangsa. Pengamal thoriqoh shufiyyah 7 adalah orang-orang yang aktif

6 Dr.Syamsu Yusuf,L.N dan Dr.A. Juntika Nurihsan. 2005: 45

7, Amalan ini di dasari dengan jalan memelihara keluar masuknya nafas, supaya hati tidak lupa kepada Allah Swt, agar senantiasa tetap akan hadirnya Allah Swt pada masuk dan keluarnya nafas, dalam menarik dan menghembuskan nafasnya, hendaklah selalu ingat serta hadir bersama Allah Swt di dalam hati sanubari, ingat kepada Allah saat keluar masuknya nafas guna memudahkan jalan dekat kepada Allah Swt dan di ridhaiNya.Kajian ini sangat berguna untuk jalan atau membuat seorang anak manusia (hamba) supaya dapat mengontrol dirinya agar jangan sampai lupa kepada Allah Swt, di samping dengan ibadah fardhu (wajib) yang di lakukan sebagai sifat penghambaan dan pengabdian terhadap Allah Swt, amalan ini jika di lakukan dengan rutin (istiqamah) dapat menjaga seorang hamba dari sifat lalai atau lupa kepada Allah Swt yang di sebabkan oleh bisikan syetan pada jalan - jalan atau pintu masuk yang halus daripada manusia, jadi inilah upaya untuk jalan menuju kepada Allah Swt yang Maha Agung dan Maha Suci.Penerapan dalam kesehariannya salah satunya menjaga jika ia (salik) berjalan, mestilah selalu menundukkan kepalanya, kalau tidak dapat di khawatirkan membuat hati bimbang dan ragu, maka dari tu kita harus memelihara hati.Terjadinya perpindahan sifat - sifat kemanusiaan yang kotor dan rendah, kepada sifat - sifat kemalaikatan yang bersih dan suci lagi penuh dengan ketaqwaan, karena itu wajiblah kita mengontrol hati, agar dalam hati kita tidak ada rasa cinta kepada makhluk selain dari Allah Swt, setiap salik harus selalu menghadirkan hati kepada Allah Swt dalam segala hal keadaan, baik di suasana sunyi maupun di tengah keramaian dunia.Suluk dalam hal ini terbagi dari 2 (dua) bagian, yakni ; Khalwat Lahir, yaitu orang yang sunyi di tengah keramaian, dan Khalwat Bathin, yaitu orang yang suluk senantiasa musyahadah kepada Allah Swt dan menyaksikan rahasia - rahasia Allah Swt, walaupun berada di tengah keramaian, dalam arti kata berkekalan dzikir (ingat) kepada Allah Swt, baik dzikir izmu zat dengan membaca Allah...Allah...Allah maupun dengan dzikir napi istbat menyebut La ilahaa illallah, sampai yang di sebut itu terlihat di dalam dzikir yang hadir dan datang.Di luar suluk yang resmi, seorang salik harus memelihara hatinya dari kemasukan sesuatu yang dapat menggoda dan mengganggunya sedapat mungkin di dalam kesadarannya yang jernih, jika terjadi yang demikian walaupun hanya sebentar dapat menjadi masaalah besar, hal ini tidak boleh terjadi dalam ajaran ibadah cara thariqat.Tawajjuh atau pemusatan perhatian sepenuhnya pada musyahadah yang menyaksikan keindahan kebesaran dan kemuliaan Allah Swt terhadap Nur Zat Ahdiyah, cahaya yang maha esa dengan tiada seumpama dengan apapun juga dan tanpa di sertai dengan kata - kata, hal ini dapat di capai oleh seorang hamba dalam menjalani ibadah cara suluk setelah dia mengalami fana dan baqo yang sempurnaPelajaran dalam ajaran ini ada mempunyai beberapa tingkatan yang di sesuaikan dengan tahap kebersihan jiwa dan hasil daripada pengamalan dzikirnya terhadap Allah Swt, dengan di bimbing oleh seorang guru mursyid tentunya pada pembelajaran ini, semakin dekat seorang hamba dengan khalikNya, maka semakin naik pulalah tahapan tingkatan kajiannya dalam memperdalam ajaran dzikir ini, tingkatan dari ajaran dzikir ini terdiri sebagai berikut :latifatul qalbiBerhubungan dengan jantung jasmani, kira - kira dua jari di bawah susu kiri, dzikirnya sekurang - kurangnya 5000 dalam sehari semalam, ini wilayahnya Nabi Adam As, cahayanya kuning dan berasal dari tanah, angin dan api. Wilayah ini tempatnya sifat buruk pada manusia, yakni ; hawa nafsu, Syetan dan Dunia, jika seorang hamba lkhlas dzikirnya pada wilayah ini, maka hilanglah itu daripadanya dan paling tidak berkurang, jadi sifat yang buruk pada wilayah ini jika di dzikirkan terus menerus, maka dapatlah menjelma atau masuklah sifat yang baik dan berakhlak, yaitu ; Iman, Islam, Tauhid dan Ma'rifat. Uraian latifah ini adalah 
merupakan sentral daripada ruhaniah manusia, wilayah ini merupakan induk dari latifah - latifah lainnya, yaitu hati sanubari manusia itu sendiri. Madzmumahnya adalah hawa nafsu yang buruk itu mengikut kepada kehendak iblis dan syetan, cinta dunia, kafir dan syirik bertempatkan pada wilayah ini. Madzmudahnya ialah Iman, Islam, Tauhid dan Ma'rifat serta sifat - sifat malaikat, melalui dzikir pada latifatul qalbiy menjelmalah sifat madzmudah tadi kedalamnya, justru inilah di tuntut seorang hamba supaya rajin - rajin membersihkan wilayah ini dengan dzikrullah. Jika seorang hamba betul - betul ikhlas dan rajin berdzikir pada wilayah ini dan beristiqamah, maka insya Allah Swt terbukalah rahasia gaib alam jabarud dan alam malakud dengan izin dan kehendakNya, dia mendapatkan ilham dan karunia daripadaNya, dan itu ini di katakan sunah dan thariqat Nabi Adam As. Puncaknya adalah fana pada Af'al Allah Swt, munculnya mati tabi'i, mati yang di maksudkan di sini adalah matinya hawa nafsu dan hiduplah hati sanubari. Mati Tabi'i artinya perasaan lahiriah orang yang berdzikir menjadi hilang, fana pendengaran dan penglihatan lahiriahnya, sehingga tidak berfungsi lagi, yang berfungsi adalah pendengaran dan penglihatan bathinnya yang memancar dari lubuk hatinya, sehingga terdengar dan terlihat adalah lapzul jalalah, dalam keadaan demikian akal dan pikiran tidak berjalan lagi, tetapi hanyalah ilham dari Allah Swt yang merupakan nur illahi itulah yang terbit dari orang yang berdzikir, sehingga hatinya muhadharoh hadir bersama Allah Swt. Mati Tabi'i juga merupakan lompatan dari pintu fana yang pertama, oleh sebab di terimanya dzikir seorang hamba oleh Allah Swt, dan ini merupakan hasil dari mujahadahnya dan merupakan rahmat dan karunia dari Allah Swt, juga merupakan fanafillah di mana gerak dan diam tidak ada kecuali dari Allah Swt. Kedua, latifatul ruhBerhubungan dengan rabu jasmani dua jari di bawah susu kanan, dzikirnya sekurang - kurangnya 1000 kali dalam sehari semalam, ini adalah wilayahnya Nabi Ibrahim As dan bercahaya merah, maqam ini berasal dari api. Maqam ini adalah tempatnya sifat madzmumah yaitu tamak, rakus dan bakhil, jika ikhlas dzikirnya maka masuklah dan berganti dengan sifat madzmudah, yaitu Khana'ah dalam arti memadai ianya akan apa ada adanya. Sifat buruk ini seperti, loba, tamak, rakus dan bakhil adalah salah satu sifat yang tidak di sukai oleh Allah Swt dan RasulNya, sifat bathiniah yang buruk seperti ini tidak ubahnya seperti binatang yang suka menurut akan hawa nafsunya, jadi dengan rajinnya mengobati sifat ini dengan dzikir pada maqam tersebut di atas adalah dapat berganti sifas yang di sukai Allah Swt dan RasulNya, seperti merasa selalu bersyukur dan menerima apa adanya yang telah di tetapkan oleh Allah Swt, usaha untuk merubah sifat ini adalah dengan cara yang wajar melalui dzikir kepada Allah Swt dengan seperti cara yang di ajarkan oleh Thariqat AnNaqsyabandi. Puncaknya pada dzikir adalah maqam fanafil asma dan mati ma'nawi, artinya semua sifat keinsanan manusia telah lebur dan lenyap di liputi oleh sifat ketuhanan yang di namakan dengan fanafisifattillah, sifat yang baharu dan sifat yang kekurangan pada diri seseorang yang berdzikir jadi lenyap atau fana, yang tinggal hanyalah sifat tuhan yang maha sempurna dan azali. Pendengaran dan penglihatan lahir menjadi hilang lenyap, yang tinggal hanyalah pendengaran bathin dan penglihatan bathin yang memancarkan nur illahi, yang terbit dari dalam hati yang dapat memancarkan ilham dari Allah Swt, mati ma'nawi ini merupakan pintu fana yang kedua dan di terima oleh seseorang berdzikir, ini merupakan hasil mujahadahnya dan merupakan rahmat dan karunia dari Allah Swt jika ikhlas dzikirnya. Ketiga, lathifatul sirriBerhubungan dengan hati jasmani kira - kira dua jari di atas susu kiri, dzikirnya dalam sehari semalam sekurang kurangnya 1000 kali, ini wilayahnya Nabi Musa As dan bercahaya putih asalnya dari angin, maqam ini tempatnya sifat madzmumah pada manusia, yaitu pemarah, pembengis, emosi tinggi dan penaik darah dan pendendam, jadi kita harus berdzikir di tempat ini jika ingin menghilangkan sifat buruk tersebut dari bathin kita, jika ikhlas dzikirnya pada tempat ini maka akan bergantilah sifat buruk tadi menjadi sifat yang terpuji, seperti pengasih, penyayang, baik budi bahasa dan pekertinya. Sifat ini di katakan seperti sifat binatang buas yang suka berbuat onar, kekejaman, penganiayaan, penindasan, permusuhan dan pendzaliman sesama, dan sebagai madzmudahnya adalah manakala lenyap sifat buruk di atas dan berganti dengan sifat kesempurnaan, terutama rahman dan rahim, ini di katakan adalah sunah dan thariqatnya Nabi Musa As. Puncaknya pada maqam ini adalah fanafisifattisubutiah dan mati sirri, mati sirri artinya segala sifat keinsanan menjadi lenyap dan berganti fana, demikian juga dengan alam yang wujud ini menjadi lenyap dan di telan oleh alam ghaib, alam malakul yang penuh dengan nur illahi, mendapat karunia mati sirri ini adalah bergelimang baqa finurillah, yaitu nur af'al Allah Swt, nur asma Allah Swt, nur zat Allah Swt dan nurron 'ala nurrin, cahaya di atas cahaya Allah Swt, di mana Allah Swt memberikan karunia itu kepada siapa saja yang dia kehendaki. Keempat, lathifatul khafiBerhubungan dengan limpa jasmani kira - kira dua jari di atas susu kanan, berdzikir pada 
maqam ini dalam sehari semalam sekurang - kurangnya 1000 kali, ini adalah wilayahnya Nabi Isa As dengan bercahayakan hitam dan berasal dari air. Ini adalah tempatnya sifat madzmumah pada manusia, seperti busuk hati, munafik, pendusta, mungkir janji, penghianat dan tidak dapat di percaya, nah jika ikhlas dzikir pada tempat ini maka hilanglah sifat yang demikian dan berganti dengan sifat yang terpuji, seperti ridha dan syukur, madzmumahnya lathifatul khafi ini di katakan dengan sifat syetaniah yang menimbulkan was - was, cemburu, dusta dan sebagainya yang sejenis, dan mahmudahnya adalah sifat syukur dan ridha serta sabar dan tawakkal, ini di katakan dengan sunahnya Nabi Isa As. Puncaknya adalah fana fissifatis salbiyah dan mati hissi, mati hissi artinya segala sifat keinsanan yang baharu menjadi lenyap atau fana dan yang tinggal hanyalah sifat tuhan yang qadim azali, ada tingkat ini tanjakan bathin seorang yang berdzikir telah mencapai tingkat tertinggi, yaitu tingkat ma'rifat, pada tingkat ini orang yang berdzikir telah mengalami keadaan yang tidak pernah di lihat oleh mata zahir, tidak opernah di dengar telinga zahir dan tidak pernah terlintas dalam hati sanubari manusia dan tidak mungkin pula bisa di sifati oleh sifat manusia kecuali yang telah di karuniakan oleh Allah Swt dengan seperti pada jalan tersebut di atas. Kelima, lathifatul akhfaBerhubungan dengan empedu jasmani kira - kira di tengah dada, dzikirnya sekurang - kurangnya dalam sehari semalam adalah 1000 kali, ini merupakan wilayahnya Nabi Muhammad Saw dan bercahaya hijau serta berasal dari tanah, tempat sifat takbur, ria, ujub dan suma'ah, ini harus kita hilangkan dengan berdzikir pada maqam ini agar dapat berganti dengan sifat tawadduk, ikhlas, sabar dan tawakkal kepada Allah Swt. Sifat segala keakuan seperti sombong, takbur, ria, loba, ujub dan tamak serta bersikap akulah yang terpandai, akulah yang terkaya, akulah yang tergagah, tercantik dan lain sebagainya, maqam ini juga di katakan dengan sifat rububiyah atau rabbaniyah dan hanya pantas bagi Allah Swt, sebab dialah yang pada hakikatnya yang memiliki, mengatur alam semesta ini, sifat baik pada maqam di dapatkan jika berdzikir dengan ikhlas adalah khusyu', tawadduk, tawakkal dan ikhlas sebenar ikhlas, selalu tafakkur akan keagungan Allah Swt dan ini di katakan dengan sunahnya dan thariqatnya Nabi Muhammad Saw, puncaknya adalah fana fidzzat, almuhallakah. Keenam, lathifatul nafsun natikah Berhubungan dengan otak jasmani terletak di tengah - tengah dahi, berdzikir pada maqam ini dalam sehari semalam adalah sebanyak 1000 kali sekurang - kurangnya, ini adalah wilayahnya Nabi Nuh As dan bercahaya biru serta tempat sifat buruk pada manusia yaitu khayal dan angan angan, oleh karena itu kikislah sifat tersebut dengan berdzikir secara ikhlas pada tempat ini, agar berganti dengan sifat muthma'innah, yaitu sifat dan nafsu yang tenang. Buruknya pada tempat ini adalah selalu panjang angan - angan, banyak khayal dan selalu merencanakan selalu yang jahat untuk memuaskan hawa nafsu, sifat baiknya adalah nafsu muthma'innah yaitu sifat yang sakinah, aman, tenteram serta berpikiran yang tenang, ini di katakan dengan sunah thariqatnya Nabi Nuh As, puncaknya adalah mati hissi. Ketujuh, lathifatul kullu jasadBerhubungan dengan selurh badan atau jasad zahir, berdzikir pada maqam ini dalam sehari semalam sekurang - kurangnya 11.000 kali, ini adalah tempatnya sifat buruk manusia, yaitu jahil dan lalai, seseorang yang dzikirnya ikhlas pada tempat ini dapat menimbulkan ilmu dan amal yang di ridhai oleh Allah Swt. Dzikir ini di sebut juga dengan dzikir sultan aulia Allah Swt, artinya raja sekalian dzikir dan di jalankan melalui seluruh badan, tulang belulang, kulit, urat dan daging di luar maupun di dalam, di tempat ini dzikir Allah...Allah...Allah pada penjuru anggota badan beserta ruas dari ujung rambut sampai ujung kaki hingga tembus keluar yakni bulu roma pada sekujur tubuh atau badan, agar dapat menghilangkan sifat malas dan lalai beribadah kepada Allah Swt. Untuk menghantam seluruh sifat malas dan lalai tersebut haruslah di laksanakan dengan sepenuh hati yang ikhlas, menurut kajian pengamal ajaran cara ibadah tasawwuf bahwa iblis dan syetan bisa masuk melalui dan menetap pada seluruh bagian tubuh, karena itu perlu di getar dengan dzikirullah sehingga dzikirullah menetap di tempat itu dengan sendirinya dan tentu saja tidak ada lagi jalan iblis atau syetan untuk dapat memasuki tubuh zahir dan merasuk kedalam bathin manusia untuk membisikkan segala perbuatan jahat yang tercela di hadapan Allah Swt. Sifat yang masuk pada maqam ini setelah dzikir tersebut adalah ilmu dan amal yang di ridhai oleh Allah Swt, dia berilmu sesuai dengan qur'an dan syari'at serta sunnah Rasul Saw, hakikat cahaya pada maqam ini adalah nuurus samawi dan di katakan dengan sunah dan thariqatnya orang alim dan ma'rifat kepada Allah Swt, puncak pada dzikir ini adalah mati hissi yang perupakan pokok dan mendasari dzikir - dzikir yang lain di atasnya, karena itu para pengamal ajaran ini harus mengkhatamkannya sekurang - kurangnya 11.000 sehari semalam. Dzikir lathaif inilah merupakan senjata paling ampuh untuk mengusir dan membasmi sifat madzmumah yang ada pada 7 (tujuh) lathaif tadi, segala sifat madzmumah atau sifat buruk ini di tunggangi oleh iblis dan syetan. 
membersihkan hati mereka untuk dekat kepada Allah Swt. Jika hati sudah suci dan kita senantiasa ingat kepada-Nya, sudah pasti akhlak dan moral kitapun akan mulia. Begitulah selanjutnya jika anak bangsa ini khususnya para elitnya sudah memiliki hati yang bersih, qolbunya terus ingat kepada Allah dimana saja berada, maka bangsa ini akan maju, bangkit dan berkeberkahan.

Dalam perjalanan sufi wajib dibimbing oleh guru, lazimnya disebu syekh atau guru mursyid. Orang-orang yang menempuh jalan sufi atas bimbingan mursyid akan memperoleh pemasrahan dalam menghidupkan kembali kesucian jiwa. Syekh dan jalan sufi adalah dua bagian yang tidak dapat dipisahkan. Karena jika ingin menempuh jalan sufi harus memperoleh bimbingan dari seorang guru, dimana didalam dunia sufi, guru atau mursyid disebut dengan Syekh.

Jika seseorang menginginkan menjajdi tenaga pengajar pada dakwah sufi seperti para mursyid diatas, maka harus memenuhi beberapa syarat, yaitu: Pertama, meninggalkan kepemilikan dan kedudukan, dan kecintaan terhadapnya. Kedua, berdamai dengan seluruh ciptaan di dunia. Tidak menyakiti siapa pun dengan perkataan maupun perbuatan, dan menyembunyikan bantuan dan kebaikan kepada siapa pun. Ketiga, menumbuhkan kemampuan untuk mandiri dan tidak bergantung kepada orang lain. Keempat, mempraktikkan keheningan didalam meditasi situasi lainnya. Kelima, kemampuan untuk merasakan dan menoleransi rasa lapar dan haus dengan berpuasa, dan dengan menurunkan ketergantungan seseorang terhadap makanan dan makan. dan syarat yang keenam, berjaga sedikit tidur dan menumbuhkan kemampuan melakukan intropeksi diri sendiri.

\section{KONSEP KONSELING ISLAM : GENEALOGI KEILMUAN}

Konseling adalah suatu kegiatan yang penting dilakukan di sekolah maupun di luar sekolah. konseling merupakan suatu aktivitas penting dalam merubah sikap dan tingkah laku individu yang irrasional menjadi rasional, yang dalam prosesnya harus dilaksanakan oleh konselor yang profesional. Dengan memperhatikan perkembangan bimbingan dan konseling di Indonesia. Hal-hal yang perlu untuk dikembangkan adalah teori dan pendekatan konseling yang sejalan dengan nilai-nilai yang dianut oleh mayoritas bangsa Indonesia. Bangsa Indonesia yang masyaraktnya mayoritas islam mestinya dalam konseling dilayani dengan pendekatan dan teknik konseling yang islami. Untuk itu pendekatan dan teori konseling yang ada perlu dimodifikasi agar tidak melanggar norma-norma islam itu sendiri.

Menyikapi permasalahan ini penulis akan membahas konsep dasar konseling islam, yang terdiri dari tiga pokok bahasan yaitu: pengertian konseling islami. landasan konseling islami dan tujuan konseling islami.Dalam literatur bahasa arab kata konseling disebut al-Irsyad atau al-istisyarah, dan kata bimbingan disebut at-taujih, dengan demikian guidance and counseling dialih bahasakan menjadi at-taujih wa al-irsyad atau at-taujih wa al-istiyarah. Secara etimologi kata Isyad berarti al-huda, add-dalalah dalam bahasa Indonesia berarti petunjuk. Sedangkan kata Istiyarah berarti talaba minh al-masyurah/an-nasihah dalam bahasa indonesia berarti meminta nasehat atau konsultasi.8 
Adanya konseling islam bersamaan dengan diturunkannya ajaran islam kepada rasulullah SAW untuk pertama kali. Ketika itu ia merupakan alat pendidikan dalam sistem pendidikan islam yang dikembangkan oleh Rasulullah. Secara spiritual bahwa Allah memberi petunjuk (bimbingan) bagi peminta petunjuk (bimbingan).Sebagai makhluk berproblem, di depan manusia telah dibentang berbagai petunjuk bagi solution (pemecahan. penyelesaian) terhadap problem kehidupan yang dihadapinya. Namun karena tidak semua problem dapat diselesaikan oleh manusia secara mandiri maka ia memerlukan bantuan seorang ahli yang berkompeten sesuai dengan jenis problemnya.

Dalam hal ini kesempurnaan ajaran islam menyimpan khazanah-khazanah berharga yang dapat digunakan untuk membantu menyelesaikan problem kehidupan manusia.Secara operasional khazanah-khazanah tersebut tertuang dalam konsep konseling islami yang secara praktis tercermin dalam proses face to face relationship (hubungan tatap muka) atau personal contact (kontak pribadi) antara seorang konselor profesional yang berkompeten dalam bidangnya dengan seorang klien yang sedang menghadapi serta berjuang menyelesaikan problem kehidupannya untuk mewujudkan amanah ajaran islam. Hidup secara tolong menolong dalam jalan kebaikan, saling mengingatkan dan memberi nasehat untuk kebaikan dan menjauhi kemungkaran9. Dengan demikian dalam konseling islami ini terjalin hubungan personal antara dua piha, satu pihak ingin meecahkan masalah dan satu pihak lain membantu memecahkan masalah.

Tohari menjelaskan bahwa konseling islami adalah suatu layanan yang tidak hanya mengupayakan mental sehat dan hidup sejahtera. Melainkan juga dapat menuntut ke arah hidup sakinah, batin merasa tenang dan tentram karena selalu dekat dengan Tuhan.10. Sedangkan Hamdani Bakran Adz-Dzaky menjelaskan bahwa konseling islami adalah suatu aktivitas memberikan bimbingan, pelajaran, dan pedoman kepada individu (klien) dalam hal bagaimana seharusnya seorang klien mengembangkan potensi akal pikirannya, kejiwaannya, keimanan dan keyakinannya serta dapat menangulangi problematika hidup dan kehidupannya dengan baik dan benar secara mandiri berdasarkan al-quran dan assunnah Rasulullah SAW.11

Sedangkan M.D Dahlan bahwa konseling islami adalah proses pemberian bantuan terhadap individu agar menyadari kembali eksistensinya sebagai makhluk Allah yang saharusnya hidup selaras dengan ketentuan dan petunjuk Allah sehingga dapat mencapai kebahagiaan hidup di dunia dan akhirat. Lebih lanjut ia menjelaskan bahwa konseling islami ini adalah bimbingan kehidupan yang pada intinya tertuju kepada realisasi doa rabbana atina fi ad-dunya wa fil al-akhirati hasanah wa qina 'azaba an-nar.12

Menurut Ahmad Badawi konseling islami adalah proses pemberian bantuan dengan adanya kontak pribadi antara pembimbing dengan siterbimbing yang dilaksanakan dalam disiplin prosedur konseling dengan berbagai tekhnik yang dilandasi oleh ajaran islam. Senada dengan pengertian diatas, menurut Anwar Sutoyo konseling islami adalah upaya membantu individu belajar mengembangkan fitrah danatau kembali kepada fitrah dengan cara

9 Syaiful, Konseling..., h. 85

10Syaiful, Konseling..., h. 85

11 Erhamwilda,Konseling..., h. 99

12 Syaiful, Konseling..., h. 85-86 
memberdayakan iman, akal dan kemauan yang dikaruniakan Allah SWT kepadanya untuk mempelajari tuntunan Allah dan Rasulnya agar fitrah yang ada pada individu berkembang dengan benar dan kokoh sesuai dengan tuntunan Allah Swt.

Dari pendapat para ahli diatas dapat di tarik sebuah kesimpulan bahwa konseling islami itu adalah proses pemberian bantuan yang dilakukan oleh konselor kepada klien, dimana proses konseling yang dilakukan bertujuan untuk mencapai ketentraman hidup manusia yang berorientasi kepada dunia dan akhirat. Pencapaian rasa tentram itu dapat diperoleh melalui pengembangan akal pikiran, kejiwaan dan keimanan kepada Allah Swt dengan cara mendekatkan diri kepadaNya yang berlandaskan Al-Qura'an dan Sunnah Rasulullah SAW.Beranjak dari definisi dan uraian tentang konseling islami seperti yang dikemukakan dari beberapa paparan pendapat di atas dapat disimpulkan beberapa rumusan pokok yaitu:Konseling islami adalah pemberian bantuan kepada klien untuk mengetahui, memahami dan mengenal keadaan dirinya sesuai dengan hakikatnya atau memahami kembali keadaan dirinya. Dengan pengertian lain mengingatkan kembali klien akan fitrahnya sebagai manusia.Konseling islami adalah layanan bantuan kepada klien untuk menerima keadaan dirinya sebagaimanan adanya. Segi-segi baik dan buruknya, kekuatan dan kelemahannya sebagai suatu yang ditetapkan Allah Swt kemudian menyadarkannya bahwa sebagai manusia ia diwajibkan berikhtiar. Kelemahan yang ada pada dirinya bukan untuk terus menerus harus disesali dan kekuatan maupun kelebihan bukan pula untuk membuat dirinya lupa diri. Dengan pengertian lain mendorong dan mengarahkan klien untuk tawakal atau berserah diri kepada Allah. Mengkonsultasikan segala permasalahan kepada Allah dan sekaligus memohon petunjuk dan pertolonganNya untuk menyelesaiakn setiap permasalahan yang dihadapi.

Konseling islami adalah serangkaian layanan bantuan kepada klien untuk memahami keadaan (situasi dan kondisi) yang dihadapinya saat ini. Dalam hal ini ia dibantu untuk merumuskan masalah yang dihadapinya dan sekaligus mendiagnosis masalah tersebut, selanjutnya membantu klien untuk menemukan sendiri alternatif pemecahan dari permasalahan yang sengaja ia hadapi. Dalam hal ini konselor hanya menunjukkan alternatif yang disesuaikan dengan kadar intelektual klien dan berdasarakan al-Qur'an dan sunnah Rasul.Konseling dalam perspektif islam. pada prinsipnya bukanlah teori baru karena ajaran islam yang tertuang dalam al-quran yang disampaikan melalui Rasulullah Saw merupakan ajaran agar manusia memperoleh kebahagiaan hidup di dunia dan di akhirat. Kebahagiaan yang dimaksud bukanlah hanya bersifat materialistik tapi lebih kepada ketentraman jiwa. ketenangan hidup dan kembalinya jiwa itu pada yang maha kuasa dalam keadaan suci dan tenang pula.Berikut beberapa landasan konseling islami yang dijelaskan Allah dalam Al-quran:13Al-quran adalah sumber bimbingan. nasehat dan doa untuk meanggulangi masalah-masalah

Q.S Yunus ayat 57

Artinya : wahai manusia sesungguhnya telah datang kepadamu suatu pelajaran dari Tuhanmu dan obat terhadap masalah-masalah yang ada petunjuk dan rahmat bagi orang-orang yang beriman. (Q.S Yunus:57)

Q.S al-isra ayat 82 
Artinya : dan kami turunkan Al-quran itu sesuatu dzat penyembuh dan rahmat bagi orang-orang yang beriman dan al-quran tidak akan memiliki nilai tambah bagi orang-orang yang berbuat aniaya melainkan hanya kerugian. (Q.S al-Isra:82).

Para rasul, nabi, auliya-Nya atau para ahli waris mereka adalah konselor dan terapis yang diutus Allah SWT.

Q.S al-baqarah ayat 151

Artinya :sebagaimana (kami telah menyempurnakan nikmat Kami kepadamu) Kami telah mengutus kepadamu Rasul diantara kamu yang membacakan ayat-ayat Kami kepada kamu dan mensucikan kamu dan mengajarkan kepadamu Al kitab dan Al-Hikmah. serta mengajarkan kepada kamu apa yang belum kamu ketahui.

Q.S Aljumu'ah ayat 2

Artinya :Dia-lah yang mengutus kepada kaum yang buta huruf seorang Rasul di antara mereka. yang membacakan ayat-ayat-Nya kepada mereka. mensucikan mereka dan mengajarkan mereka kitab dan Hikmah (As Sunnah). dan Sesungguhnya mereka sebelumnya benar-benar dalam kesesatan yang nyata.

Allah Swt adalah Tuhan yang maha konselor dan maha terapis (tidak ada kemampuan siapapun dan apapun dalam membantu manusia lain memecahkan masalahnya yang akan melebihi bantuan yang diberikan Allah kepada Qalbu manusia yang diberi-Nya petunjuk. Allah berfirman dalam surat Yunus ayat 108109 :

Artinya :.Katakanlah: "Hai manusia. Sesungguhnya teIah datang kepadamu kebenaran (Al Quran) dari Tuhanmu. sebab itu Barangsiapa yang mendapat petunjuk Maka Sesungguhnya (petunjuk itu) untuk kebaikan dirinya sendiri. dan Barangsiapa yang sesat. Maka Sesungguhnya kesesatannya itu mencelakakan dirinya sendiri. dan aku bukanlah seorang penjaga terhadap dirimu".109. dan ikutilah apa yang diwahyukan kepadamu. dan bersabarlah hingga Allah memberi keputusan dan Dia adalah hakim yang sebaik-baiknya.

Adanya kewajiban mencari jalan menuju kepada perbaikan dan perubahan dengan cara :Adanya kesungguhan dan perjuangan. Allah berfirman dalam Q.S Al maidah ayat 35 .

Artinya : Hai orang-orang yang beriman. bertakwalah kepada Allah dan carilah jalan yang mendekatkan diri kepada-Nya. dan berjihadlah pada jalan-Nya. supaya kamu mendapat keberuntungan.

Bertanya kepada ahlinya. allah berfirman dalam Q.S An-Nahl ayat 43

Artinya : dan Kami tidak mengutus sebelum kamu. kecuali orang-orang lelaki yang Kami beri wahyu kepada mereka; Maka bertanyalah kepada orang yang mempunyai pengetahuan[828] jika kamu tidak mengetahui.

Rasulullah SAW bersabda : "Tidaklah selayaknya bagi orang yang tidak berpengetahuan itu berdiam diri dalam kebodohannya. dan demikian pula tidak selayaknya bagi orang yang berilmu berdiam diri dengan ilmunya". (H.R Thabrani. Ibnu Mardawih. Ibnu Suni dan abu Naim dari Jabir RA)

kewajiban tolong menolong dalam mengadakan perbaikan dan menuju ketaqwaan. Allah berfirman dalam Q.S Al-maidah ayat 2.

Artinya : Hai orang-orang yang beriman. janganlah kamu melanggar syi'ar-syi'ar Allah dan jangan melanggar kehormatan bulan-bulan haram. jangan (mengganggu) binatang-binatang had-y adan binatang-binatang qalaa-id dan 
jangan (pula) mengganggu orang-orang yang mengunjungi Baitullah sedang mereka mencari kurnia dan keredhaan dari Tuhannya dan apabila kamu telah menyelesaikan ibadah haji. Maka bolehlah berburu. dan janganlah sekali-kali kebencian(mu) kepada sesuatu kaum karena mereka menghalang-halangi kamu dari Masjidilharam. mendorongmu berbuat aniaya (kepada mereka). dan tolongmenolonglah kamu dalam (mengerjakan) kebajikan dan takwa. dan jangan tolongmenolong dalam berbuat dosa dan pelanggaran. dan bertakwalah kamu kepada Allah. Sesungguhnya Allah Amat berat siksa-Nya.

Manusia akan susah mendapatkan kesejahteraan hidup jika meninggalkan ketentuan-ketentuan hukum-hukum Allah sebagaimana tertera di dalam al-Quran. Allah berfirman dalam Q.S Al-maidah ayat 44-45 dan ayat 47.

Artinya : Sesungguhnya Kami telah menurunkan kitab Taurat di dalamnya (ada) petunjuk dan cahaya (yang menerangi). yang dengan kitab itu diputuskan perkara orang-orang Yahudi oleh nabi-nabi yang menyerah diri kepada Allah. oleh orangorang alim mereka dan pendeta-pendeta mereka. disebabkan mereka diperintahkan memelihara Kitab-Kitab Allah dan mereka menjadi saksi terhadapnya. karena itu janganlah kamu takut kepada manusia. (tetapi) takutlah kepada-Ku. dan janganlah kamu menukar ayat-ayat-Ku dengan harga yang sedikit. Barangsiapa yang tidak memutuskan menurut apa yang diturunkan Allah. Maka mereka itu adalah orang-orang yang kafir.dan Kami telah tetapkan terhadap mereka di dalamnya (At Taurat) bahwasanya jiwa (dibalas) dengan jiwa. mata dengan mata. hidung dengan hidung. telinga dengan telinga. gigi dengan gigi. dan luka luka (pun) ada kisasnya. Barangsiapa yang melepaskan (hak kisas) nya. Maka melepaskan hak itu (menjadi) penebus dosa baginya. Barangsiapa tidak memutuskan perkara menurut apa yang diturunkan Allah. Maka mereka itu adalah orang-orang yang zalim.

Artinya : 47. dan hendaklah orang-orang pengikut Injil. memutuskan perkara menurut apa yang diturunkan Allah didalamnya. Barangsiapa tidak memutuskan perkara menurut apa yang diturunkan Allah. Maka mereka itu adalah orang-orang yang fasik.

Zulkifli Akbar mengemukakan bahwa konseling islami bertujuan membantu individu untuk memecahkan masalah kehidupan yang dihadapinya atas dasar petunjuk ajaran agama islam agar ia dapat memperoleh kebahagiaan hidup di dunia dan akhirat. Sedangkan, Munandir mengemukakan bahwa tujuan konseling islam adalah membantu seseorang untuk mengambil keputusan dan membantunya menyususn rencana guna melaksanakan keputusan itu. Dengan keputusan itu ia bertindak atau berbuat sesuatu yang konstruktif sesuai dengan perilaku yang didasarkan atas ajaran islam.

Secara garis besar dan umum tujuan konseling islami dirumuskan "membantu individu mewujudkan dirinya sebagai manusia seutuhnya agar tercapai kebahagiaan dunia dan akhirat". Membantu mewujudkan individu menjadi manusia seutuhnya disini dimaksudkan membantu mewujudkan diri sesuai dengan hakikatnya sebagai manusia. untuk menjadi manusia yang memiliki keselarasan perkembangan unsur-unsur dirinya dan pelaksanaan fungsi atau kedudukannya sebagai makhluk Allah. makhluk individu. makhluk sosial dan makhluk berbudaya. Untuk itu upaya konseling islami bermaksud membantu tumbuhnya kesadaran manusia akan hakikat jati dirinya yaitu manusia yang mengemban tugas pokok kemanusiaannya sebagai pengelola serta penata alam 
dan kehidupannya demi kesejahteraan. kemakmuran diri berikut dunianya sesuai dengan kehendak Allah dan ia harus mampu mengabdikan seluruh hidupnya untuk Allah sebagai khaliknya.Layanan konseling islami ditujukan untuk membantu manusia sedapat-dapatnya agar terhindar dari masalah. Andaipun ia harus mengalami masalah. diharapkan ia dapat menerima keadaan dirinya sebagaimana adanya. sebagai ketetapan dan anugerah Allah. Sesuai dengan dimensi spiritual dalam konseling islami. Klien dibantu untuk bersikap tawakal kepada Allah dengan menyerahkan seluruh permasalahannya kepada Allah. memohon petunjuk pertolongan dan Ridha-Nya. Ia harus mampu menjadikan Allah sebagai Konselor yang maha agung. sumber memperoleh keberanian dan kekuatan untuk penyelesaian segala masalah dan sumber ketenangan hati. Untuk itu ia diarahkan agar selalu mendekatkan diri dengan Allah dengan jalan beribadah secara nyata baik itu ibadah wajib maupun sunnah tetapi tidak boleh kehilangan keaktifan. kreativitas dan keberanian untuk bertindak.

Sedangkan dalam dimensi material, konseling islami bertujuan membantu klien untuk meningkatkan daya intelektualnya dalam menerima dan memahami permasalahannya sekaligus dapat merumuskan dan mendiagnosis agar dapat memilih alternatif penyelesaian masalah yang terbaik.Jika dihubungkan dengan fungsinya tujuan konseling islami adalah14:Secara preventif membantu klien untuk mencegah timbulnya masalah pada dirinya.Secara kuratif membantu untuk memecahkan dan menyelesaikan masalah yang dihadapinya.Secara perseveratif membantunya menjaga situasi dan kondisi dirinya yang telah baik agar jangan sampai kembali tidak baikSecara developmental membantunya menumbuhkembangkan situasi dan kondisi dirinya yang telah baik agar dapat menjadi lebih baik secara berkesinambungan sehingga menutup kemungkinan untuk munculnya kembali masalah dalam kehidupannya.

Tujuan pokok konseling islami dapat diuraikan sebagai berikut15:Membantu manusia agar dapat terhindar dari masalah.Membatu klien agar menyadari hakikat diri dan tugasnya sebagai manusia dan hamba Allah.Mendorong klien untuk tawakal dan menyerahkan permasalahnnya kepada Allah tanpa harus kehilangan keaktifan dan kreativitas serta keberanian untuk bertindak. Mengarahkan klien agar mendekatkan diri setulus-tulusnya kepada Allah dengan senantiasa beribadah secara nyata baik yang wajib maupun yang sunnat.Mengarahkan klien agar istiqomah menjadikan Allah Konselor Yang Maha Agung sebagai sumber memperoleh keberanian dan kekuatan bagi penyelesaian masalah serta sumber memperoleh ketenangan hati.Membantu klien agar dapat memahami. merumuskan dan mendiagnosis maalah dan dapat memilih alternatif terbaik penyelesaiannya.Menyadarkan klien akan potensi dan menumbuh kembangkan kemampuannya agar dapat mengantisipasi masa depannya dan jika mungkin dapat juga menjadi konselor bagi orang lain. Jadi dapat disimpulkan bahwa tujuan dari konseling islami adalah membantu klien agar mampu menyelesaikan masalahnya demi mencapai ketentraman jiwa dalam kehidupan yang sakinah dan diridhai Allah. memiliki istiqamah untuk menjadikan Allah sebagai konselor yang maha agung. Konseling islami adalah layaanan bantuan konselor kepada klien untuk menumbuhkembangkan kemampuannya dalam memahami dan menyelesaikan masalah serta mengantisipasi masa depan 
dengan memilih alternatif tindakan terbaik demi mencapai kebahagiaan dunia dan akhirat di bawah naungan ridha dan kasih sayang Allah. Landasan konseling islami Landasan dari konseling islami sudah dijelaskan Allah dalam Al-quran dan sunnah Rasulullah Saw.

\section{IPMLENTASI KONSEP KONSELING ISLAM DALAM PANDANGAN TAREKAT NAQSABANDIYAH}

Melihat dari penemuan pertama menunjukkan bahwa bimbingan konseling islam pada dakwah Tuan Guru tidak terlepas dari tauhid, bimbingan konseling akhlak maupun bimbingan konseling mauamalah. Sesuai dengan hasil observasi dan wawancara bahwa berupa penegasan tentang zikir kepada Allah SWT. jamaah senantiasa selalu mengingat Allah SWT dengan memperbanyak zikir. Selain dari menjaga kesucian badan, kesucian hati, kesucian pikiran dan kesucian pakaian adalah sangat di tegaskan oleh Tuan Guru kepada jamaahnya

Dari penjelasan di atas dapat di tangkap bahwa Tuan Guru bimbingan yang di berikan kepada jamaah tidak lepas dari tauhid, serta bimbingan konseling yang di berikan Tuan Guru menekankan pada sisi kesucian badan, kesucian hati, kesucian pikiran dan kesucian yang tujuannya adalah upaya mendekatkan diri kepada Allah SWT dan mendapatkan ketenangan dalam hidup di dunia dan juag ketenangan hidup di akhirat. Selain itu kunci utama yang diutarakan oleh Tuan Guru untuk mencapai ketenangan tersebut dengan berzikir dan selalu mengingat Allah SWT.16

Selain itu ada bimbingan konseling tentang akhlak. Bimbingan konseling akhlak ini di jelasakna oleh Tuan Guru yang dimaksudkan tentang bimbingan konseling akhlak di sini adalah akhlak bagi setiap makhluk yang ada di bumi ini seperti manusia, tumbuh-tumbuhan, maupn hewan. Di dalam majlis Tuan Guru membahas tentang akhlak manusia yang bagaimana? Yaitu akhlak dan adab seorang murid kepada gurunya, serta akhlak kepada sesama. Mereka sangat menekankan kepada adab ini karena adab ini menjadi dasar utama bagi manusia. Adab yang diajarkan adab bagaiaman cara berbicara dengan guru, adab bertanya kepada guru, adab mendengarkan pelajaran serta adab mendoakan guru semuanya di terapkan dalam sangat hati-hati.

Maksud dari pemaparan di atas adalah bahwa Tuan Guru menyeru agar menanamkan bimbingan konseling akhlak dalam kehidupan sehari-hari. Akhlak dan adab merupakan bagian yang sangat penting dalam kehiduoan sehari-hari, akhak terhadap semua makhluk yang ada akhlak kepada manusia, atau ahklak kepad tumbu-tumbuhan, bahkan akhlak kepada hewan pun juga harus dilakukan. Dari penjelasan di atas juga menejelaskan akhlak dan adab kepada guru adab yang harus dilakukan kepada guru adalah adan yang tentang berbicara kepada guru, adab bertanya kepada $\mathrm{n}$ guru serta adab untuk mendengarkan pelajaran dari guru, serta adab untuk mendoakan guru. Ini yang paling utama bahwa menghormati seorag guru itu sangat penting sekali karena dengan menghormati guru kita sama dengan menghormati orang tua kita sendiri.

Dan yang terakhir adalah bimbingan konseling muamalah, di sini diajarkan oleh Tuan Guru cara berinteraksi dengan kehidupan sosial antar sesama anggota masyarakat. Tuan Guru juga mengajarkan untuk saling menghargai, 
menghormati dan tolong menolong antar sesama makhluk Allah SWT. karena dalam thoriqoh diajarkan bahwa setiap yang ada di dunia adalah makhluk hidup yang memiliki tuhan yang sama yaitu Allah SWT, serta semuan yang ada di bumi adalah milik Allah SWT sebagai pemilik mutlak semua yang ada di bumi. Lau bagaimana dengan manusia? Manusia memiliki harta yang mereka miliki namu itu hanya titipan Allah SWT agar manusia bisa memenuhi kebutuhannya serta dapat menjaga harta tersebut, harta yang berda pada manusia hanya bersifat sementara sedangkan apa yang di miliki Allah adalah yang kekal atau bia dikatakan bahwa apa yang ada di dunia ini adalah milik Allah SWT sebagai pemilik mutlak. Ini juga di jelaskan dalam firman Allah SWT dalam surat AlFatihah : 2.

Artinya : "segala puji bagi Allah, Tuhan semesta alam"

Jadi, bimbingan konseling muamalah yang di ajarkan oleh Tuan Guru adalah interaksi sosiala di dalam kehidupan bermasyarakat dari kata muamalah ini sudah jelas bahwa interaksi yang di maksudkan adalah interaksi yang berhubungan dengan aktivitas yang di lakukan manusia dalam lingkup produksi, distribusi dan konsumsi. Guna dari produksi, distribusi dan konsumsi adalah unuttk menggenjot roda perekonomian masyarakat agar masyarakat dapat menjalankan kehidupan dengan baik. Dalam kegiatan tersebut ada unsur mencarai kerdhoan Allah atau biasa di sebut ibadah jadi setiap yang dilakukan buakn hanya mencari keuntungan semata melainkan mencari keridhoan Allah SWT.

Selain itu dijelaskan bahwa manusia di dunia hanya memiliki harta yang bersifat sementara dan harta menjadi titipan Allah agar manusia bisa menjalankan kehidupannya dengan baik dan sesuai dengan ketentuan islam. Sedangkan pemilik utama dunia ini adala Allah SWT dan seluruh isinya Allah SWT yang menjadi pemilik mutlak atas segala sesuatu.

Dalam buku Al-Rasyidinm dalam Djahiri memaknai nilai dalam dua arti, yakni : Pertama, Nilai merupakan harga yang di berikan seseorang atau sekelompok orang terhadap sesuatu yang didasarkan pada tatanan nilai (value system) yang ada dalam diri atau kelompok manusia bersangkutan. Harga yang dimaksud disini adalah harga afektual, Yakni harga yang meyangkut dunia afektif manusia.Dari makna nilai ini dapat diambil beberapa pengertian bahwa nilai merupakan haraga maksudnya adalah nilai sebagai sesuatu yang diberiakan kepada seseorang atau sekelompom terhadap sesuatu yang di dasarakan pada nilai atau bisa di dikatakan bahwa niali iu dberikan kepada seseorang atau sekelompok orang yang dianngap penting dan mendapa return keuntungan yang di dapat atas apa yang telah di beriak oleh orang tersebut.

Kedua, Nilai merupakan isi pesan, semangat atau jiwa, kebermaknaan (fungsi peran) yang tersirat atau di bawakan sesuatu.maksunya bagaimana? Maksudnya adalah nilai adalah isi pesan atau suatu kata yang dapat membangkitkan semangat atau jiwa yang dibawakan sesuatu. Contoh, Al-Qur'an memiliki nilai atau harga sebagai kitab kumpulan wahyu ilahi sehingga mendapatkan kedudukan "suci, dihormati, dan lain-lain". berdasarkan dua pengertian Djahiri menyimpulkan "nilai adalah harga yang di berikan oleh seseorang atau sekelompok orang terhadap sesuatu (materiil, immanteril, personal, kondisional) atau harga yang di bawakan tersirat menjadi jati diri manusia.

Dari apa yang sudah dijelaskna dari atas dapat di tarik pengertian dari bimbingan konseling islam pada dakwah sufi adalah sebagian pedoman dalam 
menjalankan syariat islam yang dapat membawa seseorang dalam suatu kebaikan dan juga bisa membawa kelompok kedalam kebaikan. Pada bimbingan konseling islam yang di lakukan oleh Tuan Guru dapat di ambil kesimpulan bahwa yang diajarkan oleh Tuan Guru tidak menyimpang dari ajaran agama islam. Baik materi yang sudah di ajarkannya maupun dari cara penerapan yang dilakukan. Dari sinilah banyak yang muali mengikutinya mulai dari intelektual, pengusaha, politisi, aparat, praktisi, serta masyarakat biasa.

Melihat penanaman bimbingan konseling yang dilakukan oleh Tuan Guru dilakukan dengan bentuk pengajian, ceramah da halaqoh. Selain dari 3 ini bimbingan konseling yang dilakukan Tuan Guru melalui riyadhoh atau berkhalwat. Melalui riyadhoh ditanamkan bimbingan konseling tauhid, bimbingan konseling akhlak dna bimbingan konseling muamalah. Menurut Huitt, tujuan pendekatan ini adalah pertama, Untuk memasukkan atau menginternalisasikan nilai-nilai kedalam diri peserta didik, dan kedua,untuk merubah nilai-nilai yang di pedoman mursyid agar lebih dekat mereflesikkan niali-nilai tertentu yang diinginkan. karena bertujuan untuk memasukkan dan meninternalisasikan nilai-nilai ke dalam sistem nilai peserta didik, maka metode bimbingan konseling yang di pandang efektif dalam implementasi pendekatan ini antara lain adalah indoktrinasi, pembiasan, keteladanan, pengutan positif, dan negatif, permainan game dan simulasi dan permainan peran.17

Maksudnya demi untuk mewujudkan bimbingan konseling yang efekti dengan menggunakan pendekatan dan mengaplikasikan nilai-nilia baik pada para peserta didik atau kepaa murid-murid dan juga dengan cara merubah nilai-nilai pedoman mursyida agar lebih dekat mencotohkan nilai-nilai tertentu yang diinginkan dengan memberikan ajaran lebih mendalam, pembiasaan, keteladanan, penguatan sisi positif, dan negatif seperti permainan game dan simulasi permaina jadi Hutt ingin mmengaplikasikan dan mewujudkan kepada peserta didik dengan memberikan ajaran mendalam tentang suatu hala yang mana sebab dan akibat apabila peserta didik melakukan suatu hal atau secara sederhana memberikan pandangan kepada peserta didik apakah yang dilakukan oleh peserta didik itu benar atau salah.

Dalam kaitanya dengan penanaman bimbingan konseling Islam, AlRasyidin dalam kutipan diatas menegaskan bahwa pendekatan penanaman nilai (inculcation approach) adalah sebuah pendekatan bimbingan konseling yang menekankan pada penanaman nilai-nilai (valuses inculcation)kedalam diri peserta didik. Yakni bimbingan konseling tauhid, bimbingan konseling akhlak dan bimbingan konseling muamalah dimasukkan kedalam diri mursyid. Kendatipun demikian, nilaii-nilai dalam dakwah sufi ini cara memasukkan atau menerapkan nilai-nilai tersebut adalah dilakukan dengan bentuk pengajian.

Dalam pendekatan tentang bimbingan konseling adal pendekatan nilai yang harus di perkuat dan juga penanaman nilai-nilai kebaikan dalam diri peserta didik dengan menggunakan bimbingan konseling tauhid, bimbingan konseling akhlak dan bimbingan konseling tauhid serta bimbingan konseling muamalah yang harus ada dalam diri mursyid muapun dalam dakwah serta pengajian harus ada bimbingan konseling tauhid, akhlak dan juga muamlah sehingga setiap apa

17Wawancara dengan para murid Tuan Guru, tanggal 14 Januari 2020. 
yang disamoaikan tidak selalu monoton yang mebuta para peserta didik bosan dengana pa yang disampaikan oelh mursyid.

Ceramah dan halaqoh juga dilakukan dengan riyadhoh, yakni dikenal dengan suluk atau berkhalawat. Senada dengan pengertian sufi menurut KBBI, bahwa sufi adalah mereka mendalamai tasawuf, yakni ilmu yang mendalami sikap jiwa untuk senantiasa berakhlak mulia, memiliki sikap mental yang selalu memelihara kesucian diri, beribadah, hidup sederhana, rela berkorban untuk kebaikan dan selalu bersikap bijaksana.

Jadi ceramah yang disampaikan oleh sufi memiliki dasar yang jelas dan dengan penyampaian yang bijaksana sehinggan bisa untuk di dengarkan oleh orang lain selain itu untuk memenuhi menjadi seorang sifi harus lah memiliki beberapa sifat yang diantaranya seperti rajin beribadahm hidup sederhana tidak harus mewah, rela berkorban untuk kebaikan. Etiap orang belum tentu bisa jadi sufi karena keberadaanyang begitu bagi kehidupan masyarakat apabila sufi salah memeberikan pengertian terhadap masyarakat yang dijarkan dapat emberi akaibat fatal yang tak bisa di toleransi.

Sehingga dapat di ambil kesimpulan bahwa penanaman bimbingan konseling islami yang dilakukan oleh Tuan Guru di tujukkan dengan penanaman nilai bimbingan konseling tauhid sebagai wujud menekatakan diri kepada Allah denga cara berzikir ian yang setiap harinya kepada Allah SWT, bimbingan konseling akhlak, akhlak merupakan bagian yang paling penting untuk kehidupan karena di situ diatur adab kepada sesama manusia, tumbuh-tumbuhan dan juga hewan.

Dalam akhlak ini yang nantinya dapat memberikan rasa menghormati apalagi yang ditanamana oleh Tuan Guru adalah penanaman akhlak kepada guru bagaimana bersikap kepada guru selayaknya yang natinya dapat mengambil brkah dalam ilmunya dalam bertutur kata kepada guru, bertanya mendengarkan apa yang disampaikan oleh guru ini begitu penting nantinya untuk mendapatkan bekah dari ilmu guru tesebut, bimbingan konseling muamalah di mana di sini diatur tentang bagaiamana kalian berinteraksi dengan msyarakat sosaila serta mengatur tentantang kepemilikan harta yang manusia punya agar sadar mereka mempunyai harta ini sebagai titipan dari Allah hanya untuk memenuhi kehidupan sehari-hari dan pemilik mutlaknya adalah Allah SWT. 3 bimbingan konseling ini lah yang harus di miliki oleh mursyid yang harus ditanamankan kepada dirinya sendiri agar ketiak penyampaian ceramah yang di sampaikan oleh mursyid tidak membosankan para jemaah atau peserta didik.

\section{KESIMPULAN}

Bimbingan konseling yang lakukan oleh Tuan Guru ada beberapa hal yang harus dikatahui bahwa ada 3 bimbingan konseling tauhid, bimbingan konseling akhlak, dan bimbingan konseling muamalah yang di jelaskan sebagai berikut : pertama, bimbingan konseling tauhid, disini mengatur tentang kebebasana manusia dalam tindakan-tindakan yang atur oleh tauhid. Bimbingan tauhid memebreikan rasa damai kebapa individu yang memiliki masalah dan mendekatakan diri kepada Allah dengan car berzikir kepada Allah SWT setiap harinya yang mebuat kebahagian dalam kehidupan dunia dan akhirat.

Kedua bimbingan konseling akhlak, dalam bimbingan konseling akhlak diajarakan tentang bagaiamana adab dalam kehidupan sehari-hari seperti adab 
terhadap sesama manusi serta adab kepada tumbuh-tumbuhan maupun dalam adab kepada hewan. Yang dia ajarkan oleh Tuan guru tentanng adab ini adalah adab terhadap guru dimana adab terhadap guru ini begitu penting karena adab ini agar mendapat berkah dari ilmu yang di berikan akhlak terhadao guru meliputi adab tentang bagaimana seni berbicara dengan guru tersebut, dan adab bertanya kepada guru tersebut serta adab mendengarkan dari apa yang disampaikan oleh guru tersebut.

Ketiga, bimbingan konseling muamalah, dalam bimbingan konseling mualamah ini di ajarkan bagaimana cara berinteraksi kepada masyarakat sosial bukan hanya itu dalam bimbingan konseling muamalah ini diajarkan untuk menghargai orang lain serta semua yang ada di bumi ini adalah milik Allah SWT dan apa yang diberikan kepada kita manusia hanya sebgai titipan dari Allah SWT untuk menjamin kehidupan kita di dunia dan mengajarkan tentang maumalah berhubungan dengan kegiatan produksi, distribusi serta konsumsi dimana ini mecari keuntunagn demi kemajuan hiup di duni bukan ahnay itu dalam mauamalh ini harus selalu semua diatkan kepada Allah apa yang kita kerjakan ini sudah tercantum dalam firman Allah Al-Fatihah :2.

Setiap mursyid harus menguasai bimbingan konseling tauhid, bimbingan konseling akhlak dan bimbingan konseling muamalah. Agar setiap apa yang di bicaraka tidak selalu monoton dan mbuat bosan, menurut Huiit harus ada pengimplematsiakan dan kajian lebih mendalam terhadap suatu maslaah sert memebri pandangan bahawa apa yang dilakukan itu benar atau salah jadi peran dari musyid ini begitu kompleks agar para peserta didik bisa mengerti apa yang dilakukan salah atau benar. Serta cerminan pada peserta didik ini begitu penting terutama pada bimbingan konseling muamalah ini di era modern seperti ini perlu sekali para musyid benar-benar menguasai tentang ilmu mualamah ini karena dengan muamalah ini lah yang nantinya dapat memengaruhi setiap aspek kehidupan. Jadi agar tidak selalu berbicara agama yang bisa membuat ara peserta didik bosan akan hal tersebut.

Serta penaman dalam bimbingan konseling islam dalam dakeah Tuan Guru di awali dengan bentuk pengajian, ceramah dan memebntuk halaqoh. Selajutnya pengajian dilakukan setiap 1 bulan sekali serta yang makin lama makin mengakomodir seluru jamaah yang ada dari sini mulai berubah dari bagian cermaha yang makin meluas menjadi tampat penegmbangan imu pengetahuan yang banayk mengungdang para intelektual datang dan tertarik bukan hanya para inteletktual banyak yang lainnya dari politikus hingga pada masyarakat biasa datang demi mencari ilmudar Tuan Guru . 


\section{DAFTAR PUSTAKA}

A. Mas"eAdi, Ghufron. (2002). Fiqih Muamalah Kontekstual. Jakarta: Raja Grafindo Persada.

Ahmad Suryadi, Rudi. (2018). Ilmu Pendidikan Islam. Yogyakarta: Deepublish.

Ahmad, Musnad. No Hadis 8595. Ensiklopedia Hadis, Kutubut Tis"ah, Kitab Musnad Sahabat yang banyak meriwayatkan hadis, Bab: Musnad Abu Hurairah Radhiyallahu , anhu.

Bayat Muhammad Ali Jamnia, Mojdeh. (2003). Negeri Sufi. Jakarta: Lentera.

D. Marimba, Ahmad. (1993). Pengantar Filsafat Pendidikan. Bandung: Al-Maeearif. Daradjat, Zakiah. (2000). Ilmu Pendidikan Islam. Jakarta: Bumi Aksara.

el Qurtuby, Usman. (2012). Alquran Qordoba Special for Muslimah. Bandung: PT Cordoba Internasional Indonesia.

Faizah dan Muchsin Effendi, Lalu. (2018). Psikologi Dakwah, Jakarta: kencana. Gazalba, Sidi. (1981). Sistematika Filsafat. jakarta: bulan bintang.

J. Moleong, Lexy. (2000). Metodologi Penelitian Kualitatif. bandung: Remaja Rosda Karya.

Masy"ari, Anwar. (1993). Butir-butir ProblematikaDakwahIslamiah.Surabaya: PT. Bina Ilmu Offset.

Munir Amin, Syamsul. (2008). Rekonstruksi Pemikiran Dakwah Islam. Jakarta: Amzah.

Muslim, Shahih. No Hadis 2674. Ensiklopedia Hadis, Kutubut Tis"ah, Kitab Ilmu, Bab: Barang Siapa membuat contoh yang baik.

Qurais Shihab, M. (1996). Wawasan Al-Qur"an. Bandung: Mizan.

QuraisH Shihab, M. (1992). Membumikan Al-Qur"an, Fungsi dan Peran Wahyu Dalam Kehidupan Masyarakat. Bandung: Mizan.

Salim (2018). Metodologi Penelitian Kualitatif. Bandung: Cita Pustaka Media. Salminawati. (2011). Filsafat Pendidikan Islam Membangun Konsep Pendidikan Yang Islami. Bandung: Cita Pustaka Media Perintis.

Sufimuda , Ahmad. (2013). Perjalanan Sufimuda Menemukan Tuhan Dalam keseharian. Medan: QM. Publishing.

Syaiful Akhyar Lubis. Konseling Islami. Yogyakarta. eLSAQ Press. 2007.

Erham wilda. Konseling Islami. Yogyakarta. Graha Ilmu. 2009 
